\title{
Utilizing the ASPeCt sea ice thickness data set to evaluate a global coupled sea ice-ocean model
}

\author{
Ralph Timmermann ${ }^{1}$ \\ Institut d'Astronomie et de Géophysique Georges Lemaître, Université Catholique de Louvain, Louvain-la-Neuve, Belgium \\ Anthony Worby \\ Department of the Environment and Heritage, Australian Antarctic Division and the Antarctic Climate and Ecosystems \\ Cooperative Research Centre, Kingston, Tasmania, Australia
}

Hugues Goosse and Thierry Fichefet

Institut d'Astronomie et de Géophysique Georges Lemaître, Université Catholique de Louvain, Louvain-la-Neuve, Belgium

Received 11 December 2003; revised 14 April 2004; accepted 20 May 2004; published 22 July 2004.

[1] Simulated sea ice thickness in the ORCA2-LIM coupled sea ice-ocean model is compared with thicknesses from the Antarctic Sea Ice Processes and Climate (ASPeCt) database. We find a qualitative agreement of the large-scale patterns of ice thickness distribution. Regional averages for the various sectors of the Southern Ocean yield a very good correspondence between observations and model data. Exceptions are the eastern Bellingshausen and northwestern Weddell Seas. A poor representation of the Antarctic Peninsula in the atmospheric forcing data and the related overestimation of westerly winds in this region lead to a spurious accumulation of sea ice on the western side of the peninsula and to an underestimation of sea ice coverage on the eastern side. Since the spatial scale of observations is not comparable to the size of a model grid cell, there is little agreement between individual observations and the corresponding model ice thicknesses. A model analysis of the seasonal and interannual variability indicates that the ASPeCt data underestimate the climatological ice thickness in the central and southern Weddell Sea and the eastern Ross Sea by up to $1 \mathrm{~m}$. Because of a winter bias in the observations an overestimation of similar magnitude is expected in the Bellingshausen Sea. Ice thickness data in most of the Indo-Pacific sector appear to be representative for the long-term climatology. A model estimate of the bias is used to compute a revised distribution of climatological sea ice thickness. INDEX TERMS: 4255 Oceanography: General: Numerical modeling; 4207 Oceanography: General: Arctic and Antarctic oceanography; 4215 Oceanography: General: Climate and interannual variability (3309); KEYWORDS: Southern Ocean, sea ice thickness, ASPeCt

Citation: Timmermann, R., A. Worby, H. Goosse, and T. Fichefet (2004), Utilizing the ASPeCt sea ice thickness data set to evaluate a global coupled sea ice-ocean model, J. Geophys. Res., 109, C07017, doi:10.1029/2003JC002242.

\section{Introduction}

[2] The role of sea ice in the world climate system is strongly related to its thickness. Sea ice thickness determines the volume of fresh water stored in a given ice pack area. It also affects the conductive heat flux through the ice cover and thus the ocean-atmosphere heat exchange. Furthermore, the thickness of sea ice determines its reaction to external stresses: Whether a convergence of ice floes results in rafting or ridging strongly depends on the ice thickness. If the ice is thick enough, it might develop considerable resistance toward convergence or even shearing. Thus the

\footnotetext{
${ }^{1}$ Now at Alfred Wegener Institute for Polar and Marine Research, Bremerhaven, Germany.

Copyright 2004 by the American Geophysical Union. 0148-0227/04/2003JC002242\$09.00
}

ice thickness affects the ice drift on a local to regional scale as much as it is affected by the drift itself.

[3] Dynamic-thermodynamic sea ice models [e.g., Lemke et al., 1990; Fichefet and Morales Maqueda, 1997] therefore feature the ice thickness as a prognostic variable. It is used to compute the conductive (vertical) heat flux through the ice [Semtner, 1976] and to parameterize the ice strength [e.g., Hibler, 1979], which in turn affects the sea ice growth rates and drift, respectively. Validation of a model's sea ice thickness distribution is thus essential to ensure a realistic representation of nature's high-latitude processes.

[4] No single strategy for comprehensively observing sea ice thickness currently exists. Observations using upward looking sonars (ULS) [e.g., Strass and Fahrbach, 1998] provide very accurate measurements of ice thickness but are limited to the very small footprint of the instrument. Ship observations, on the other hand, offer the broadest coverage 
but have historically been kept in many different formats and have often been qualitative. The use of satellite data to estimate ice thickness is still not possible, although altimetry measurements promise to yield some thickness data in the Arctic and the thicker regions of the Antarctic sea ice zones in the not too distant future [e.g., Laxon et al., 2003].

[5] To improve our understanding of Southern Hemisphere sea ice, the Antarctic Sea Ice Processes and Climate (ASPeCt) program has been launched by the Scientific Committee on Antarctic Research. One of the major accomplishments of ASPeCt since its inception in 1997 is the specification of a standard protocol for sea ice thickness observations made aboard ships in the Antarctic pack ice. Ships entering the Antarctic pack ice zone at any time of year have been encouraged to record sea ice observations and to send them to a central data archive at the Antarctic Cooperative Research Centre located in Hobart, Australia. Recorded observations include the total ice concentration and an estimate of the areal coverage, thickness, topography, and snow cover of the three thickest ice categories within a $1 \mathrm{~km}$ radius from the ship [Worby, 1999]. From these observations, estimates of the mean ice thickness (including both deformed and undeformed ice) are derived [Worby et al., 1998]. The resulting data set provides distributions of sea ice properties and thickness with a much greater areal coverage than is currently available from satellite products. The ship-based thickness observations are not of sufficient accuracy for climate monitoring, but there are sufficient data in most regions and seasons to give a good estimate of the ice thickness distribution.

[6] This paper presents a comparison of the ASPeCt data set with the sea ice thickness simulated in the Antarctic sector of the ORCA2-LIM global coupled sea ice-ocean model [Timmermann et al., 2004]. Besides assessing the model performance, the goal of this study is to investigate whether the ASPeCt data set is prone to bias produced by an (inevitable) undersampling of the natural sea ice cover. We start with the introduction of the model and the data set used. Section 3 features the comparison between the model and observed ice thicknesses, going through a hierarchy of methods. A discussion and summary of our findings conclude the paper.

\section{Model and Data}

\subsection{Model Description}

[7] The ocean component of the ORCA2-LIM global coupled sea ice-ocean model is based on version 8.2 of the hydrostatic, primitive equation ocean model Océan Parallélisé (OPA) [Madec et al., 1999]. It has been coupled to the Louvain-la-Neuve sea ice model (LIM) [Fichefet and Morales Maqueda, 1997; Goosse and Fichefet, 1999], which is a dynamic-thermodynamic model specifically designed for climate studies. It features a viscous plastic rheology, a three-layer model for the thermodynamics, and a snow-ice conversion scheme. Sea ice thickness in this model refers to the mean thickness of the ice pack, including deformed and undeformed portions but excluding open water. Therefore it is not an ice volume per unit grid cell area as in the coupled model of, for example, Timmermann et al. [2002] but is really the mean thickness in the icecovered part of the grid cell.
[8] The coupled model is run on a global grid with $2^{\circ}$ nominal resolution and a mesh refinement in high latitudes and near the equator. Vertical discretization uses $31 \mathrm{z}$ levels, with 10 levels in the top $100 \mathrm{~m}$. Model runs are initialized using data from the end of the 46-year experiment described by Timmermann et al. [2004]. Atmospheric forcing fields are a combined data set consisting of the National Centers for Environmental Prediction/National Center for Atmospheric Research (NCEP/NCAR) daily 1949-2001 reanalysis data of 10-m wind speed and 2-m temperature [Kalnay et al., 1996] and monthly climatologies of relative humidity [Trenberth et al., 1989], total cloudiness [Berliand and Strokina, 1980], and precipitation [Xie and Arkin, 1996]. A correction of ocean surface fresh water fluxes has been derived from the time mean restoring salinity flux diagnosed from the experiment described by Timmermann et al. [2004]. Further details of the coupled model are given by Timmermann et al. [2004] as well.

\subsection{ASPeCt Sea Ice Thickness Data Set}

[9] For this study, a data set of 18,114 observations from the ASPeCt data archive was used. Although the data set spans the period 1981-2001, most of the data are from the 1990s. Sea ice records have been converted into a mean ice thickness following Worby et al. [1998]. Errors in ice thickness are estimated to be $\pm 20 \%$ of total thickness for level ice. Errors may be greater in areas of deformed ice, where a simple function of undeformed ice thickness, average sail height, and fractional area ridged is used to determine mean ice thickness [Worby and Allison, 1999].

[10] To allow for a quantitative comparison with ORCA2LIM model output, observed ice thicknesses have been gridded into $2^{\circ} \times 2^{\circ} \cos \phi$ cells (with $\phi$ denoting the latitude) identical to the model grid. An average over all observations available for each grid cell was computed. Since the model ice thickness directly refers to the mean thickness of the ice pack, open water areas are not taken into account. A circumpolar map of the resulting data (Figure 1) indicates their inhomogeneous regional coverage: The Indian and western Pacific sectors have the densest coverage of data points, typically with $10-50$ observations per grid cell. Other regions, such as the central Weddell Sea, have a much more sparse data coverage, and in some cases, individual voyage tracks can still be identified. Large areas of the Ross Sea are covered with data representing about 10 observations per grid cell; the central Weddell Sea features only scattered data with typically only about 5 observations in each grid cell.

\section{Data Comparison}

\subsection{Real-Time Sampling}

[11] To allow for a quantitative comparison between modeled and observed data in this region of high seasonal and interannual variability, we use a daily output of simulated sea ice thickness and sample the model data for the times and positions of all suitable ASPeCt observations. Since each of these model data represents a snapshot corresponding to the specific dates of the individual observations, we will refer to this data set as real-time sampled (RTS) model data. 


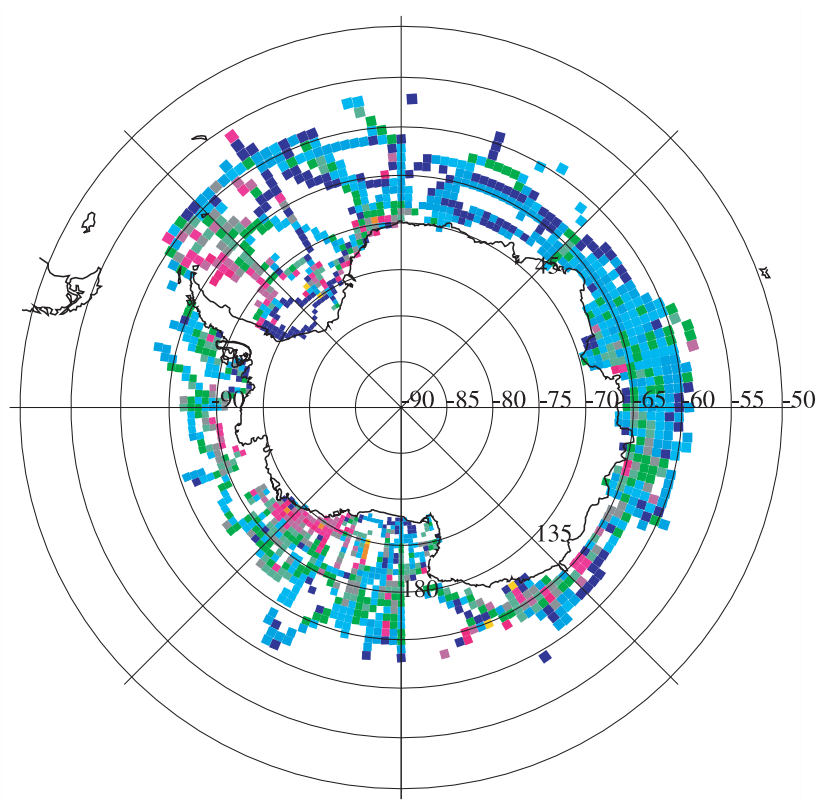

$\begin{array}{llllllllllll}0.00 & 0.20 & 0.40 & 0.60 & 0.80 & 1.00 & 1.25 & 1.50 & 2.00 & 3.00 & 4.00 & 5.00\end{array}$
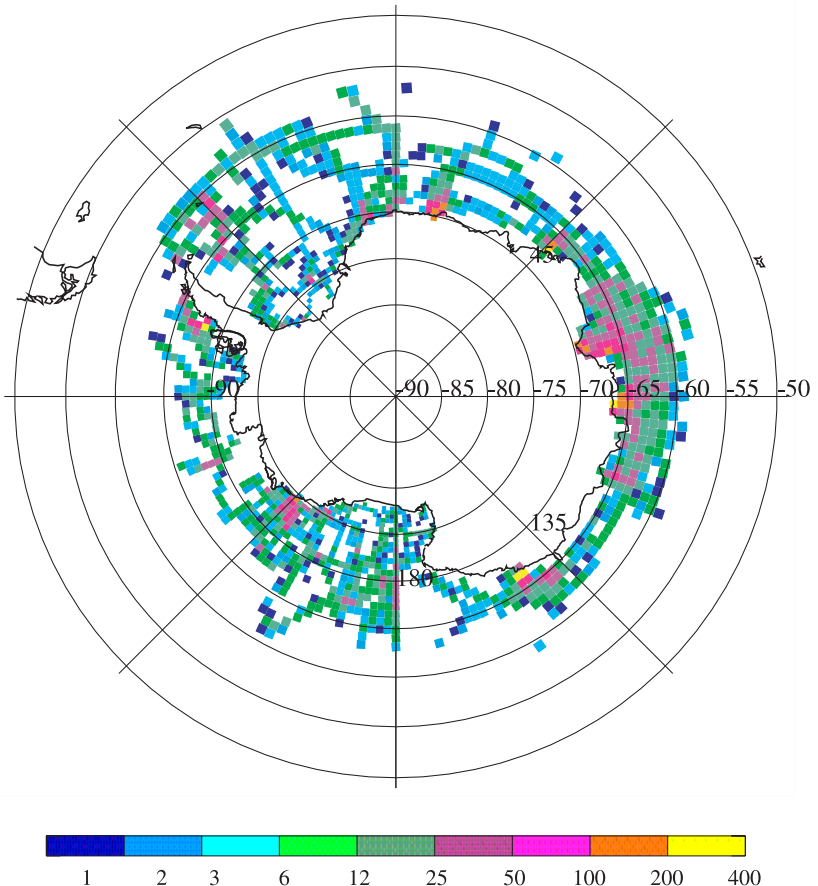

Figure 1. (left) ASPeCt mean ice thickness data $(\mathrm{m})$ gridded onto the ORCA2-LIM model grid and (right) the number of observations in each grid cell. Note the nonlinear color scales for both plots.

[12] To gain insight into the regional distribution of thickness and errors, we split the circumpolar data into five sectors. In agreement with Gloersen et al. [1992] we define the Weddell Sea sector from $60^{\circ} \mathrm{W}$ to $20^{\circ} \mathrm{E}$, the Indian Ocean sector from $20^{\circ} \mathrm{E}$ to $90^{\circ} \mathrm{E}$, the western Pacific Ocean sector from $90^{\circ} \mathrm{E}$ to $160^{\circ} \mathrm{E}$, the Ross Sea sector from $160^{\circ} \mathrm{E}$ to $130^{\circ} \mathrm{W}$, and the Amundsen and Bellingshausen Seas (ABS) sector from $130^{\circ} \mathrm{W}$ to $60^{\circ} \mathrm{W}$. Since previous studies have indicated a systematic underestimation of modeled sea ice volume along parts of the Antarctic Peninsula [Timmermann et al., 2004], we use the $45^{\circ}$ meridian to subdivide the Weddell Sea sector into the western and eastern Weddell Sea.

[13] Scatterplots of the resulting data pairs (Figure 2) indicate that the agreement between the modeled sea ice thicknesses and the corresponding observations is poor. Given that observations from an area with a $1 \mathrm{~km}$ radius are compared with data from a model with about $80 \mathrm{~km}$ horizontal resolution, this is hardly surprising. The ship observations show the pack ice to be a highly variable and complicated mix of different ice types. Their concentration, thickness, and topography may vary significantly over short spatial scales. However, for about $50 \%$ of the data set the difference between observations and real-time sampled model data is smaller than $40 \mathrm{~cm}$.

[14] For an observed ice thickness below $1.2 \mathrm{~m}$ the majority of points in the eastern Weddell Sea and the Ross, Amundsen, and Bellingshausen Seas are found well above the $1 / 1$ line, which indicates that the model tends to overestimate the thickness of thin ice. Simulated ice thicknesses, especially in the Ross Sea and the western Pacific sector, seem to gather between 1 and $1.2 \mathrm{~m}$, which is close to the equilibrium thickness that can be achieved by purely thermodynamic sea ice growth [Harder and Lemke, 1994].
On the other hand, observed thicknesses larger than 1.5$1.8 \mathrm{~m}$ appear to be underestimated in all sectors except for the Ross, Amundsen, and Bellingshausen Seas. Thus it appears that thermodynamic sea ice growth in the model is too fast, so the equilibrium thickness is reached too soon, while the effect of dynamic thickening appears to be underestimated.

[15] An outstanding exception to this finding is the western Weddell Sea, where the model consistently and substantially underestimates sea ice thickness. The underestimation of ice thickness in the northwestern Weddell Sea was already found in a comparison of ORCA2-LIM simulated ice thicknesses to data derived from upward looking sonars (ULS) [see Timmermann et al., 2004] and can also be seen in other coupled sea ice-ocean models forced by the NCEP/NCAR reanalysis $2 \mathrm{~m}$ temperatures [e.g., Fichefet et al., 2003]. It is mainly attributed to a poor representation of the Antarctic Peninsula in the NCEP/NCAR reanalysis model, especially north of $68^{\circ} \mathrm{S}$, which causes a warm bias in the near-surface temperature fields and, even more important, spurious westerlies in this region [Windmüller, 1997]. Using this data set to force a dynamic-thermodynamic sea ice model drives the ice offshore and prevents the formation of the thick, heavily deformed multiyear ice that is actually found in this region. Possible contributions by deficiencies in the model physics are discussed in section 4.

[16] Another outstanding region is the Amundsen and Bellingshausen Seas sector in which the model appears to overestimate sea ice thickness systematically. Splitting the data into seasons (Figure 3) reveals that this is the only sector in which the majority of observations was made during the austral winter months: $72 \%$ of the observations are from July, August, or September. Furthermore, the vast majority of the data in the ABS sector were collected in a narrow region close to the Antarctic Peninsula (near Mar- 

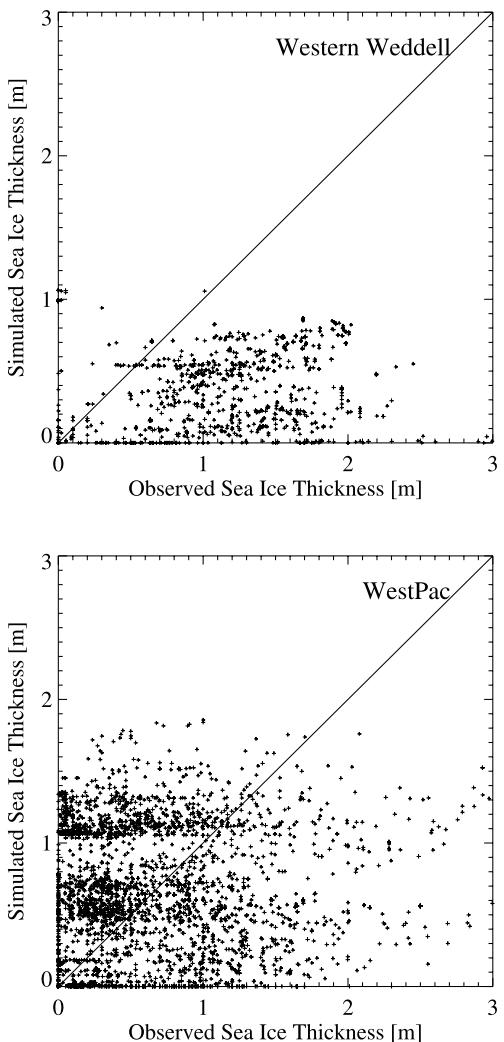
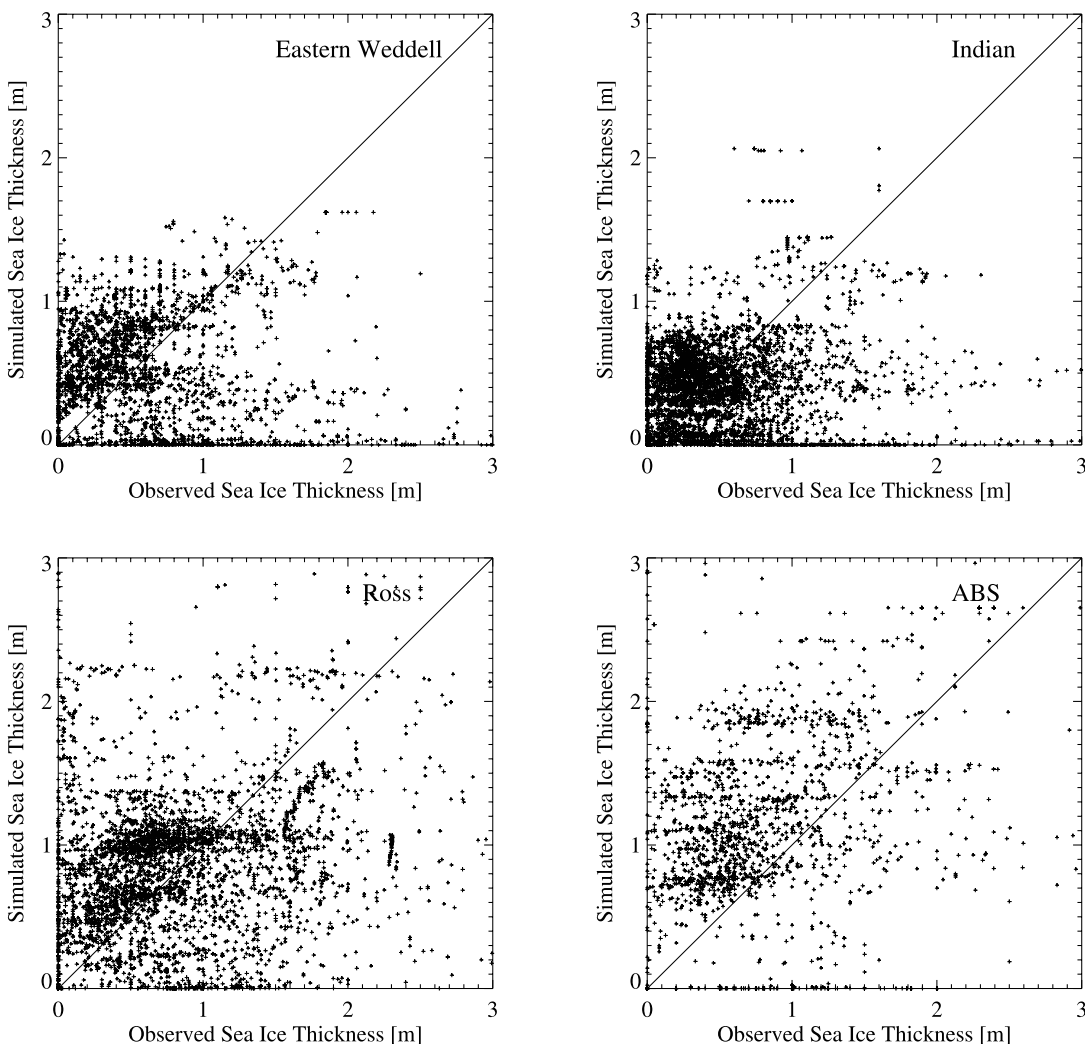

Figure 2. Scatterplots of real-time sampled (RTS) model sea ice thicknesses versus ASPeCt observations in the interval from 0 to $3 \mathrm{~m}$, which comprises $98.7 \%$ of the available ASPeCt data set. Model ice thicknesses have been extracted corresponding to the time and location of each ASPeCt observation. Data have been divided into the western and eastern Weddell Sea sectors, the Indian Ocean sector, the western Pacific Ocean sector, the Ross Sea, and the Amundsen and Bellingshausen Seas (ABS). The solid line is the $1 / 1$ line.

guerite Bay; see Figure 1, right), which represents a rather small part of the sector.

[17] From the scatterplots in Figure 3 (top) it appears that outside the ABS sector the maximum model ice thicknesses are found in austral summer and autumn. However, seasonal splitting of the ASPeCt data set (not shown) reveals that the regions of maximum ice thickness, that is, near the coast of the Antarctic continent, were sampled only during the summer months and in early autumn (for obvious reasons of accessibility), so the RTS model data extraction does not give any results from the thick ice regions during winter and early spring. Finding that the model seems to capture the very thick ice only in December-February thus is merely a sampling bias due to the fact that the regions with the thickest model ice cannot be reached by ship in any other season.

[18] A striking feature in Figures 2 and 3 is that simulated ice thicknesses appear to aggregate along horizontal lines. The reason for this again is the underestimation of smallscale spatial and temporal variability of sea ice thickness in the model. If the ship changes position only slowly or resamples an area already visited a short time ago (e.g., in the context of station work or supply tasks), it may encounter very different sea ice conditions, while in a few days the model fields change only very little. Therefore these lines do not indicate that the model prefers certain ice thicknesses; they only reflect the scarce sampling in some regions or ice thickness regimes and the low small-scale variability in the model.

\subsection{Local and Regional Averaging}

[19] To allow for a comparison of the regional sea ice thickness distribution, real-time sampled (RTS) model ice thicknesses have been gridded on the ORCA2-LIM model grid following the same procedure as for the observed sea ice thickness data (see section 2.2). Maps of the resulting mean model ice thicknesses (Figure 4, left) and of the difference from the mean observed thicknesses (Figure 4, right) indicate that although differences can be quite substantial, most of the qualitative features of the large-scale sea ice distribution agree rather well between the model and the observational data set. Simulated ice thickness is overestimated in most of the Weddell Sea sector, with the pronounced exception of the northwestern Weddell Sea near the Antarctic Peninsula, where ice thickness is underestimated by $1 \mathrm{~m}$ and more. The thin ice in the Indian Ocean and western Pacific sectors follows the observations quite realistically; typical differences in this region are smaller than $0.25 \mathrm{~m}$.

[20] Sea ice thickness distribution in the Ross Sea shows a strong spatial variability in both the RTS model ice thickness and the ASPeCt data. In general, the thin ice in the north is captured reasonably well, while toward the south and near the coast, simulated ice thickness appears to 

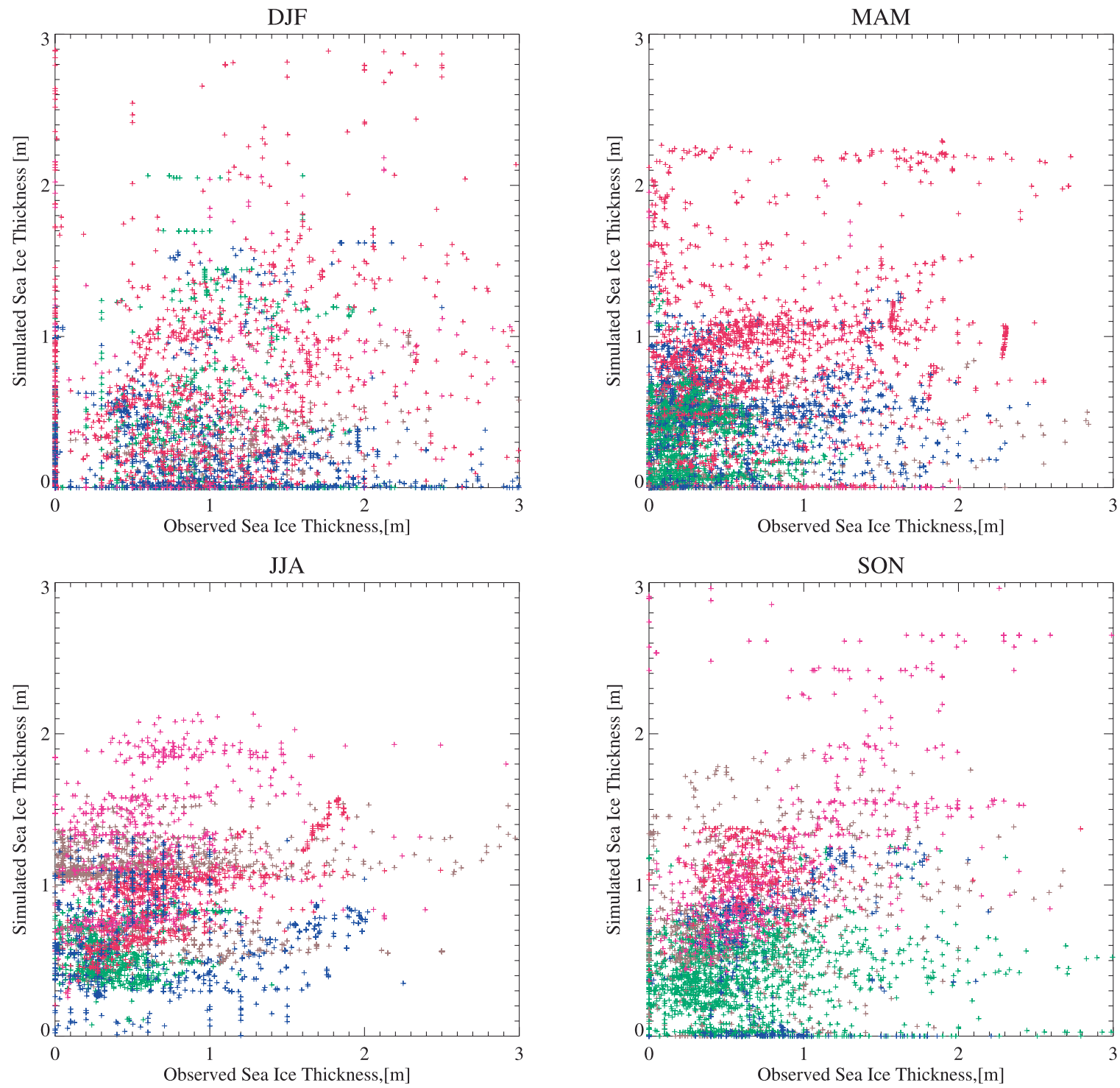

Figure 3. Scatterplots of RTS model sea ice thicknesses versus ASPeCt observations for December, January, and February (DJF); March, April, and May (MAM); June, July, and August (JJA); and September, October, and November (SON). Colors refer to the Weddell Sea (blue), Indian Ocean sector (green), western Pacific sector (brown), Ross Sea (red), and Amundsen and Bellingshausen Seas (pink).

be overestimated. With an overestimation of almost $2 \mathrm{~m}$ in a couple of near-coastal grid points in the eastern Ross Sea and near Cape Adare, the Ross Sea features the biggest differences of the whole comparison.

[21] Sea ice thickness in most of the Amundsen and Bellingshausen Seas agrees reasonably well with the observations; most of the grid cells feature an error of less than $0.25 \mathrm{~cm}$. The slight overestimation of thickness along the ice edge in this sector can be attributed to the ice extent in this region being slightly too large [Timmermann et al., 2004].

[22] As expected from the previous analysis, the model overestimates ice thickness by typically $1 \mathrm{~m}$ in the region immediately west of the Antarctic Peninsula. This is consistent with the assumption of a poor representation of the Antarctic Peninsula in the forcing data (see section 3.1). An overestimation of westerly winds in this region is bound to produce an accumulation of sea ice on the western side of the peninsula and an underestimation of sea ice coverage on the eastern side. Whether a bias in the observations due to the local choice of voyage tracks contributes to the discrepancy has to remain as an open question.

[23] Therefore even after averaging the observations over areas corresponding to a model grid cell, errors can still be substantial. This is not surprising, as the pack is known to diverge and converge on short temporal scales, driven by the highly variable atmospheric forcing and also by tides. Obviously, this strongly affects the ice thickness distribution. Sea ice model forcing consists of daily means for the atmosphere and does not consider tidal movements in the ocean and thus cannot cover these high-frequency variations.

[24] However, condensing the data further by computing sector-wide mean ice thicknesses (Figure 5) yields a very good agreement for most regions: Except for the western Weddell Sea and the ABS sector, mean modeled and 


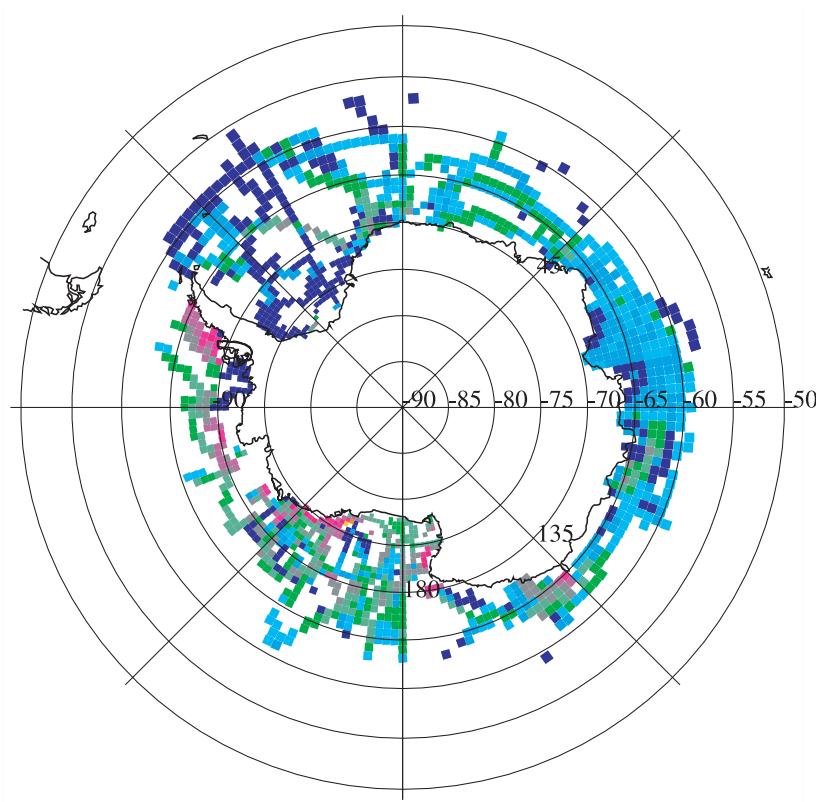

$\begin{array}{llllllllllll}0.00 & 0.20 & 0.40 & 0.60 & 0.80 & 1.00 & 1.25 & 1.50 & 2.00 & 3.00 & 4.00 & 5.00\end{array}$

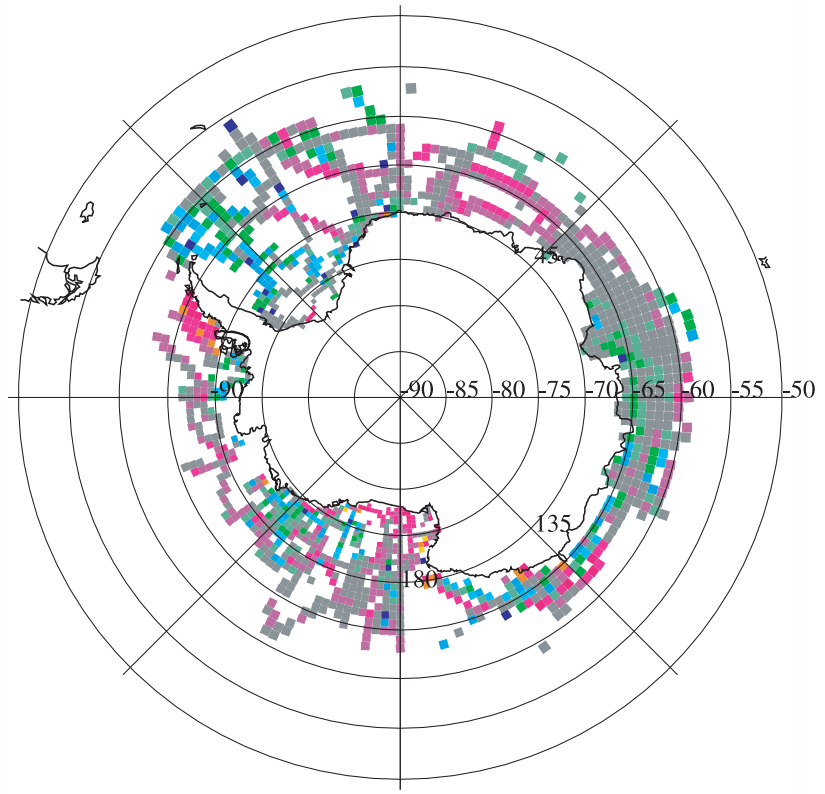

$\begin{array}{llllllllllll}2.00 & -1.50 & -1.00 & -0.75 & -0.50 & -0.25 & 0.25 & 0.50 & 0.75 & 1.00 & 1.50 & 2.00\end{array}$

Figure 4. Composite means of (left) the real-time sampled (RTS) simulated sea ice thicknesses (m) and (right) the differences from the observed thickness (m).

observed ice thicknesses agree very well in all the sectors. The maximum mean sea ice thickness is found in the Ross Sea and the minimum in the Weddell Sea and Indian Ocean sectors, all very close to the climatology derived from ASPeCt data. The western Weddell Sea stands out as a region of significantly underestimated sea ice thickness.

[25] In contrast to the western Weddell Sea, the ABS sector features a significant overestimation of area-mean ice thickness. However, excluding the grid points immediately west of the Antarctic Peninsula from the averaging leads to a very good agreement for the remaining sector (pink triangle in Figure 5).

[26] Finally, the overall mean (plus or minus standard deviation) Antarctic sea ice thickness is $0.73 \pm 0.77 \mathrm{~m}$ for the ASPeCt data and $0.63 \pm 0.55 \mathrm{~m}$ for the real-time sampled model data. This indicates that the model slightly underestimates both the circumpolar mean sea ice thickness and its spatial variability.

\subsection{Climatological Mean Ice Thickness}

[27] The goal of this section is to investigate whether a long-term mean model ice thickness distribution can reasonably be evaluated by comparison with the ASPeCt data set. This implies the assessment of possible bias in the observational data.

[28] As the ASPeCt data naturally include only observations with sea ice actually present, the mean simulated ice thickness $\bar{h}$ is computed considering only grid cells with $h>$ $10^{-3} \mathrm{~m}$. The 1981-2001 mean distribution of simulated sea ice thickness (Figure 6, left) in the 50-year experiment analyzed here is very similar to the map published by Timmermann et al. [2004] featuring a predominantly zonal distribution with a mean ice thickness between 0.6 and $0.8 \mathrm{~m}$ in the central Ross and Weddell Seas. Maximum ice thickness in the Weddell Sea does not exceed $2 \mathrm{~m}$ and is found on the southern continental shelf. In the Ross Sea sector, maximum ice thickness between 2 and $3 \mathrm{~m}$ is found on the eastern continental shelf while the Ross polynya in the western Ross Sea is the origin of newly formed, relatively thin ice that is exported northward along the $180^{\circ}$ meridian. Deformation at the coast near Cape Adare leads to a maximum ice thickness of about $2 \mathrm{~m}$ in this region. In the Indian Ocean and the western Pacific sectors, mean model sea ice thickness typically does not exceed $1 \mathrm{~m}$ even at the coast; in a large area near Prydz Bay we find a mean simulated sea ice thickness between 0.4 and $0.6 \mathrm{~m}$.

[29] Comparing these data with the mean observed sea ice thicknesses (Figure 1) reveals some qualitative agreement but also a number of discrepancies. Similar to the assessment of RTS model data (section 3.2), simulated ice thickness appears to be overestimated in most of the Weddell Sea, with the pronounced exception of the northwestern Weddell Sea near the Antarctic Peninsula. Differences from the ASPeCt climatology can be as large as $1.5 \mathrm{~m}$, which converts to a relative error of more than $100 \%$ in some places. However, the qualitative distribution with thick ice in the west and thin ice in the east is captured reasonably well, as is the occurrence of thicker ice near the coast.

[30] The thin ice in the Indian Ocean and western Pacific sectors again follows the observations quite closely. In the Ross Sea the data sets agree about the thin ice in the north, while toward the south and near the coast the simulated ice thickness is significantly larger than in the ASPeCt climatology. However, the general distribution featuring the thickest ice in the central Ross Sea and thinner ice farther north (toward the Antarctic Circumpolar Current) and south (Ross polynya and surrounding region along the Ross Ice Shelf), and patches of thick ice along the eastern Ross Sea 


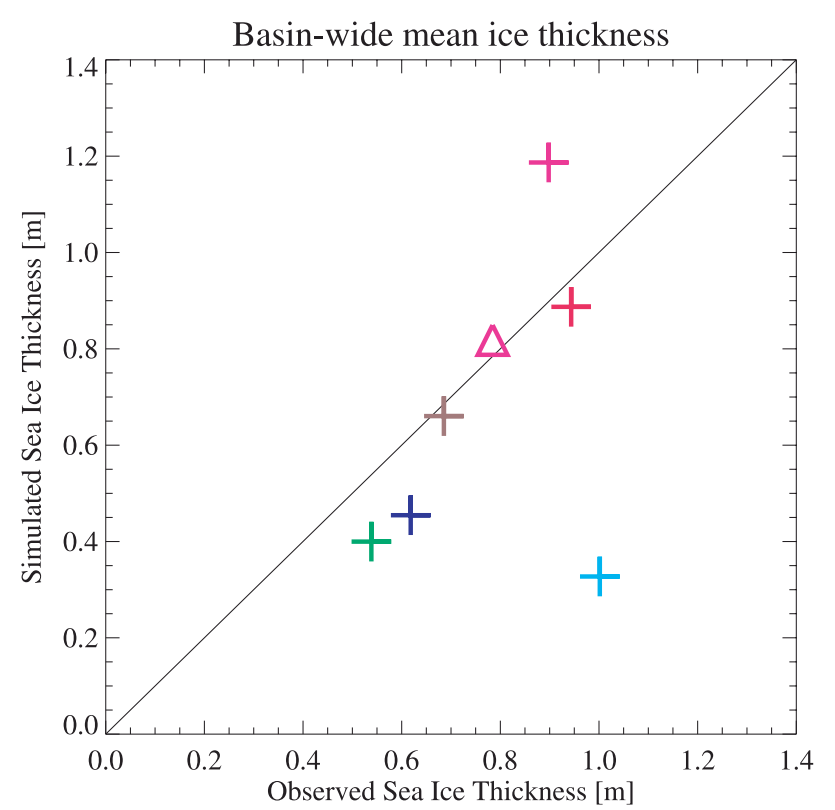

Figure 5. Sector-wide averages of RTS model sea ice thickness and the corresponding ASPeCt observations. Crosses refer to the western Weddell Sea (light blue), the Weddell Sea east of $45^{\circ} \mathrm{W}$ (dark blue), the Indian Ocean sector (green), the western Pacific sector (brown), the Ross Sea (red), and the Amundsen and Bellingshausen Seas (pink). The pink triangle refers to the average over the ABS seas, excluding the data immediately west of the Antarctic Peninsula. The solid line is the $1 / 1$ line.

coast, is in good agreement with the mean ASPeCt ice thickness.

[31] Sea ice thickness in the Amundsen and Bellingshausen Seas again agrees well with the observations. The already known exception is the eastern Bellingshausen Sea along the coast of the Antarctic Peninsula, where the model sea ice is significantly thicker than indicated by the ASPeCt climatology.

[32] Comparing the long-term mean model ice thickness (Figure 6, left) with the RTS thicknesses (Figure 4, left) reveals a number of significant differences. Using the time mean model data, simulated ice thickness in the southwestern Weddell Sea and on the track along the $30^{\circ} \mathrm{W}$ meridian appears to be heavily overestimated, while the analysis of RTS model data (section 3.1) features a good agreement. Real-time sampled ice thickness in the southwestern Weddell Sea does not exceed $0.2 \mathrm{~m}$ for most of the data points, while the long-term mean model ice thickness at these locations ranges between 0.8 and $1.5 \mathrm{~m}$. Thus the very low observed ice thickness in the southwestern Weddell Sea (Figure 1) can clearly be attributed to a seasonal and/or interannual sampling bias, simply because of the fact that this region is accessible by ship only in years and seasons with a comparatively thin ice cover.

[33] Therefore, beyond the scope of model evaluation, this paper yields some information about how representative individual observations in the ASPeCt data set are. Regions with a large difference between the long-term mean and the real-time sampled model ice thickness (Figure 6, right) are prone to feature substantial bias in the mean observed ice thickness due to seasonal or interannual variability. Besides the central and southwestern Weddell Sea, this appears to be true in the eastern Ross Sea. In both regions the RTS model ice thicknesses are typically $0.5-1.5 \mathrm{~m}$ smaller than the long-term means. Apart from isolated points spread across the model domain, there are only a few locations in the western Pacific sector and in the Amundsen and Bellingshausen Seas where the RTS model ice thickness is higher than the long-term mean. Again, the eastern Bellingshausen Sea coast stands out; it is the only region where the longterm mean model ice thickness is more than $0.75 \mathrm{~m}$ smaller than the RTS thickness, which can be easily explained by the fact that most observations in this region are from winter months.

[34] We conclude that the ASPeCt data underestimate the climatological sea ice thickness in the central and southern Weddell Sea and the eastern Ross Sea by up to $1 \mathrm{~m}$ (and even more on single grid points) because of undersampling and a bias toward summer and/or thin ice years when ships could traverse the region. We expect an overestimation of similar magnitude in the Bellingshausen Sea because of a winter bias in the observations. Ice thickness data in most of the Indo-Pacific sectors appear to be representative of the long-term climatology of sea ice thickness. These results are not affected by the choice of the period for which the model climatology is computed: Using only a decadal mean for the period 1991-2001 instead of the 2-decade average for 1981-2001 (shown in Figure 6, left) yields differences of up to $0.3 \mathrm{~m}$ in the central Weddell Sea (indicating a negative trend in the ice thickness here), but since the typical bias in this region is between 0.6 and $0.9 \mathrm{~m}$ (Figure 6, right), interdecadal variability does not seem to play a crucial role here.

\section{Discussion and Conclusions}

[35] We have presented the utilization of the ASPeCt sea ice thickness data set for the evaluation of a global coupled sea ice-ocean model. We found little agreement between individual observations and the corresponding model ice thicknesses. Averaging the data to $2^{\circ} \times 2^{\circ} \cos \phi$ cells identical to the ORCA2-LIM model grid still yields major differences between the model and the observations on a grid cell scale but also reveals qualitative agreement in several large-scale features of the sea ice thickness distribution. These agreements include the occurrence of very thin ice in the Indian Ocean and the western Pacific sectors and the occurrence of local sea ice thickness maxima along the Antarctic coast.

[36] Condensing the data set even further to regional averages for the Weddell Sea, the Indian Ocean sector, the western Pacific sector, the Ross Sea, and the Amundsen and Bellingshausen Seas yields a very good agreement between the observations and the model data. However, a poor representation of the Antarctic Peninsula in the NCEP/ NCAR reanalysis data and the related overestimation of westerly winds in this region lead to an accumulation of the sea ice on the western side of the Peninsula and to an underestimation of sea ice coverage on the eastern side, both of which are clearly notable in the data comparison. Apart from these regions, and although the agreement is rather poor for individual data pairs, the comparison indi- 


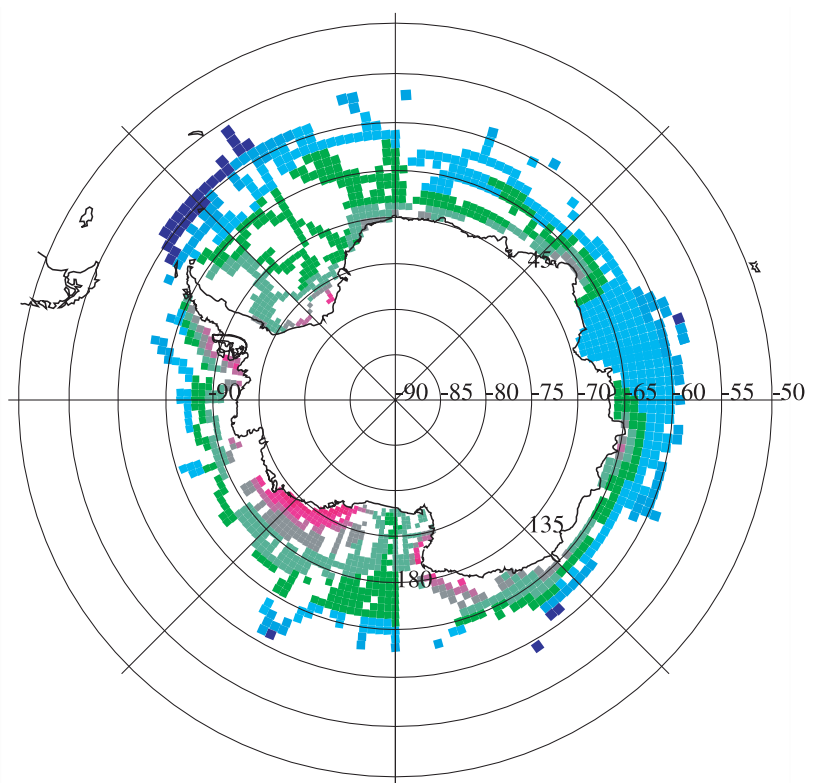

$\begin{array}{llllllllllll}0.00 & 0.20 & 0.40 & 0.60 & 0.80 & 1.00 & 1.25 & 1.50 & 2.00 & 3.00 & 4.00 & 5.00\end{array}$

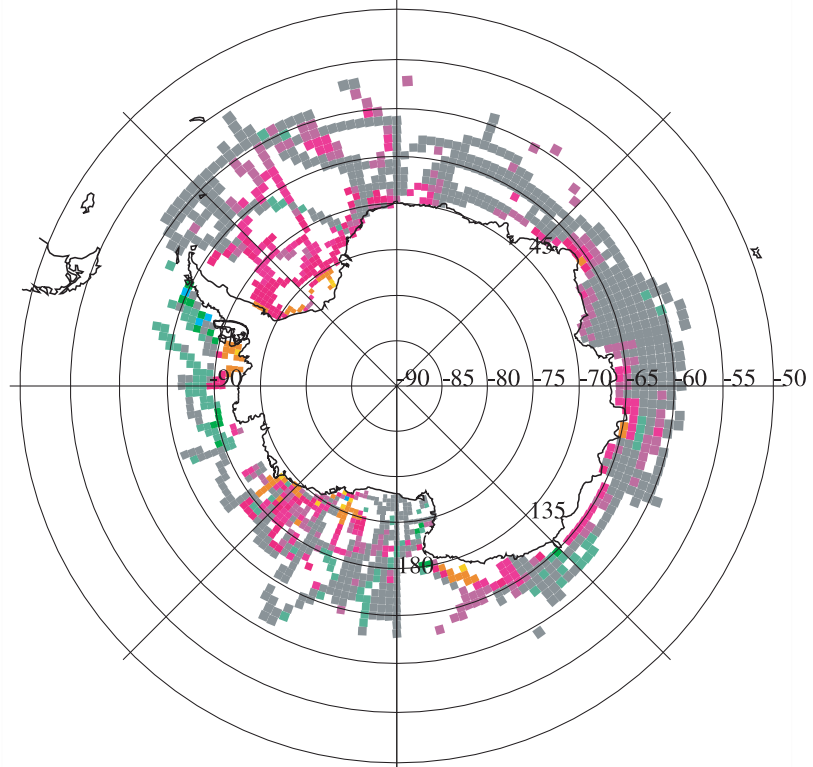

$\begin{array}{llllllllllll}-2.00 & -1.50 & -1.00 & -0.75 & -0.50 & -0.25 & 0.25 & 0.50 & 0.75 & 1.00 & 1.50 & 2.00\end{array}$

Figure 6. (left) Simulated 1981-2001 mean sea ice thickness (m) on ASPeCt data points and (right) the difference from the RTS model ice thickness. Note the nonlinear color scales.

cates that the basin-scale sea ice thickness in the ORCA2LIM model is in good agreement with observations.

[37] These findings are consistent with a comparison with Weddell Sea ULS data [Strass and Fahrbach, 1998; Harms et al., 2001] that indicated a good agreement of modeled and observed ice thickness in the central Weddell Sea and a pronounced underestimation near the Antarctic Peninsula [Timmermann et al., 2004]. The problem of different spatial scales resembles the findings of Rothrock et al. [2003], who, after a comparison of modeled sea ice thickness with observed ice draft from submarine cruises in the Arctic Ocean, report a good agreement for the draft averaged over entire cruises but a weaker correlation for spatial patterns on a 50-km horizontal scale. Holloway and Sou [2002] revealed the large sampling error in the submarine data set as being problematic when using the data to derive an estimate for a decrease in total Arctic ice volume; it is thus reasonable to apply similar caution when using ship-based observations.

[38] A general tendency to overestimate the thickness of thin ice together with the underestimation of ice thicknesses larger than $1.5 \mathrm{~m}$ indicates that the model thermodynamic sea ice growth is too fast, so an equilibrium thickness is reached too soon, while the impact of dynamics (i.e., rafting and ridging) is underestimated. From the Ice Station Weddell buoy array, Geiger et al. [1998] found that while ice drift in the western Weddell Sea is primarily controlled by the winds, ice deformation is largely driven by tidal/inertial forcing at diurnal and semidiurnal scales. This type of driving is not represented in the model, a deficiency that is likely to contribute to the underestimation of ice thickness in regions with thick ice and especially in the northwestern Weddell Sea.

[39] This is in line with the findings of Tin et al. [2004], who investigated the relative significance of dynamic and thermodynamic processes along simulated sea ice trajectories in the Ross Sea and found that the importance of dynamic thickening tends to be underestimated. While the Tin et al. [2004] sea ice model (which was derived from the Bremerhaven Regional Ice-Ocean Simulations (BRIOS-2) coupled sea ice-ocean model [Timmermann et al., 2002; Assmann et al., 2003]) differs from LIM in the treatment of sea ice thermodynamics, sea ice dynamics are described in a very similar way, using the Hibler [1979] viscous plastic approach with the same set of rheology parameters. Thus it yields results rather close to those of ORCA2-LIM, which allows for the models to be compared and makes the above argument sustainable.

[40] The poor agreement of individual modeled and observed ice thicknesses and the comparatively smooth model ice thickness distribution in circumpolar maps both point to the fact that the model underestimates small-scale variability considerably. For a $2^{\circ} \times 2^{\circ} \cos \phi$ model forced by atmospheric data with about $210 \mathrm{~km}$ horizontal resolution, this is hardly surprising. Furthermore, the model ice thickness is assumed to be an average over the ice-covered part of the grid cell; there is no information about the ice thickness distribution within the grid cell. The introduction of a multicategory ice thickness distribution following the ideas of Haapala [2000] is expected to yield a considerable improvement in the representation of regional-scale sea ice dynamics and thermodynamics.

[41] Finally, the substantial difference between the longterm mean model ice thickness and a composite map derived from model data sampled at time slices corresponding to the individual ASPeCt observations indicates that in scarcely sampled regions the ASPeCt data set is subject to a serious seasonal or interannual bias. In most regions the bias is toward thin ice, but the fact that most of the observations in the eastern Bellingshausen Sea are from 


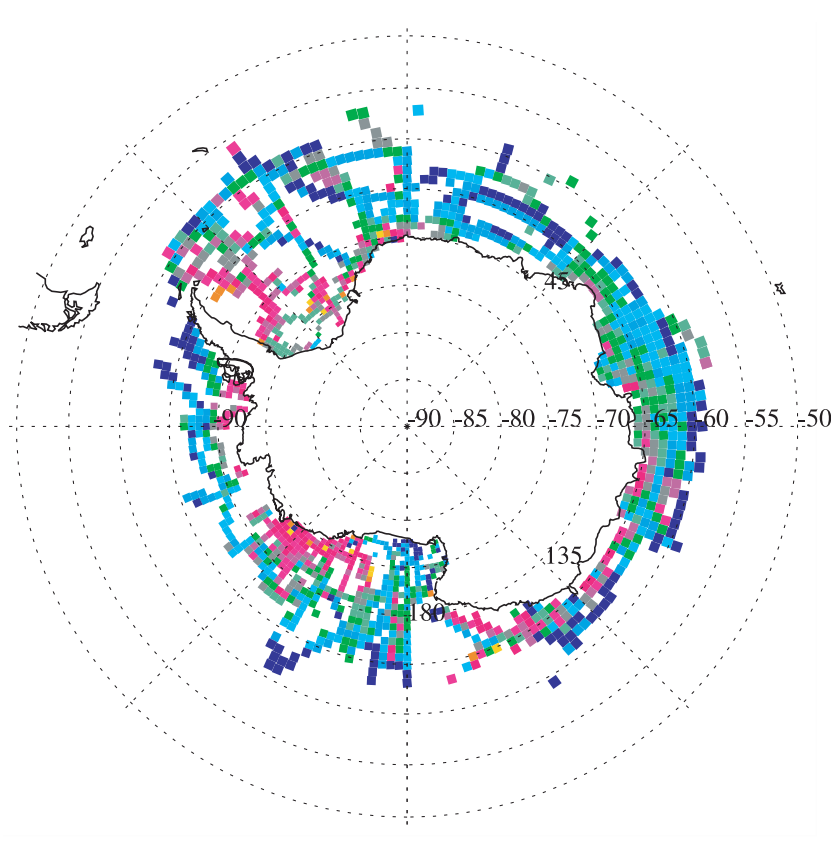

$\begin{array}{llllllllllll}0.00 & 0.20 & 0.40 & 0.60 & 0.80 & 1.00 & 1.25 & 1.50 & 2.00 & 3.00 & 4.00 & 5.00\end{array}$

Figure 7. ASPeCt mean ice thickness data $(\mathrm{m})$ gridded onto the ORCA2-LIM model grid corrected by a model estimate of the sampling bias.

winter months was found to lead to a significant overestimation of the climatological ice thickness here. Further errors in the $\mathrm{ASPeCt}$ data set may arise from limited accessibility and the choice of cruise tracks. The use of electromagnetic measurement techniques [e.g., Haas, 1998] on an airborne platform [e.g., Multala et al., 1996], which is currently becoming operational in the Arctic (C. Haas, personal communication, 2003), will ease this problem at least on a local to regional scale.

[42] Until then, to avoid problems arising when utilizing the ASPeCt data set for model evaluation, it appears necessary to sample the model data at time slices corresponding to the individual observations. If this is not possible (as, for example, in coupled climate general circulation models, which do not necessarily provide a hindcast of specific years as do stand-alone ice-ocean models forced by atmospheric reanalysis data), the difference between the real-time sampled and the climatological mean model data (Figure 6, right) can serve as a guideline for the bias to be expected. We are confident that adding the data from Figure 6 to the mean ASPeCt ice thickness (Figure 1) gives a good estimate of the Antarctic ice thickness distribution (Figure 7) representative of the last 2 decades.

[43] Acknowledgments. Thanks go to M. Vancoppenolle for inspiring discussions and to the reviewers for their helpful comments. The NCEP/ NCAR reanalysis data were provided by the National Oceanic and Atmospheric Administration Cooperative Institute for Research in Environmental Sciences Climate Diagnostics Center, Boulder, online at http:// www.cdc.noaa.gov. Interpolation to the ORCA2-LIM grid was done by V. Dulière and K. Rodgers. T. Fichefet and H. Goosse are research associates with the Belgian National Fund for Scientific Research. This work was undertaken while A. Worby was a visiting professor at the Université Catholique de Louvain (UCL), Louvain-la-Neuve. It was carried out as part of the Second Multiannual Scientific Support Plan for a
Sustainable Development Policy (Belgian State, Prime Minister's Services, Federal Office for Scientific, Technical, and Cultural Affairs, contracts EV/ $10 / 7 \mathrm{D}$ and $\mathrm{EV} / 10 / 9 \mathrm{~A})$, the French project of operational oceanography MERCATOR, and the Action Concertée Initiative Changement Climatique (project Changement Climatique et Cryosphère) from the French Ministry of Research. Support from each of these, and from UCL itself, is gratefully acknowledged.

\section{References}

Assmann, K., H. H. Hellmer, and A. Beckmann (2003), Seasonal variation in circulation and watermass distribution on the Ross Sea continental shelf, Antarct. Sci., 15, 3-11.

Berliand, M. E., and T. G. Strokina (1980), Global Distribution of the Total Amount of Clouds (in Russian), 71 pp., Hydrometeorol. Publ., St. Petersburg, Russia.

Fichefet, T., and M. A. Morales Maqueda (1997), Sensitivity of a global sea ice model to the treatment of ice thermodynamics and dynamics, J. Geophys. Res., 102(C6), 12,609-12,646.

Fichefet, T., B. Tartinville, and H. Goosse (2003), Antarctic sea ice variability during 1958-1999: A simulation with a global ice-ocean model, J. Geophys. Res., 108(C3), 3102, doi:10.1029/2001JC001148.

Geiger, C. A., S. F. Ackley, and W. D. Hibler III (1998), Sea ice drift and deformation processes in the western Weddell Sea, in Antarctic Sea Ice: Physical Processes, Interactions and Variability, Antarct. Res. Ser. vol. 74, edited by M. O. Jeffries, pp. 141-160, AGU, Washington, D. C.

Gloersen, P., W. J. Campbell, D. J. Cavalieri, J. C. Comiso, C. L. Parkinson, and H. J. Zwally (1992), Arctic and Antarctic sea ice, 1978-1987: Satellite passive-microwave observations and analysis, NASA SP, vol. 511, Natl. Aeronaut. and Space Admin., Washington, D. C.

Goosse, H., and T. Fichefet (1999), Importance of ice-ocean interactions for the global ocean circulation: A model study, J. Geophys. Res., 104(C3), $23,337-23,355$.

Haapala, J. (2000), On the modelling of the ice thickness redistribution, J. Glaciol., 46, 427-437.

Haas, C. (1998), Evaluation of ship-based electromagnetic-inductive thickness measurements of summer sea-ice in the Bellingshausen and Amundsen Seas, Cold Reg. Sci. Technol., 27, 1-16.

Harder, M., and P. Lemke (1994), Modelling the extent of sea ice ridging in the Weddell Sea, in The Polar Oceans and Their Role in Shaping the Global Environment, Geophys. Monogr. Ser., vol. 85, edited by O. M. Johannessen, R. D. Muench, and J. E. Overland, pp. 187-197, AGU, Washington, D. C

Harms, S., E. Fahrbach, and V. H. Strass (2001), Sea ice transports in the Weddell Sea, J. Geophys. Res., 106(C5), 9057-9074.

Hibler, W. D., III (1979), A dynamic thermodynamic sea ice model, J. Phys. Oceanogr., 9(4), 815-846.

Holloway, G., and T. Sou (2002), Has Arctic sea ice rapidly thinned?, J. Clim., 15, 1691-1701.

Kalnay, E., et al. (1996), The NCEP/NCAR 40-year reanalysis project, Bull. Am. Meteorol. Soc., 77, 437-471.

Laxon, S., N. Peacock, and D. Smith (2003), High interannual variability of sea ice thickness in the Arctic region, Nature, 425, 947-950.

Lemke, P., W. B. Owens, and W. D. Hibler III (1990), A coupled sea icemixed layer-pycnocline model for the Weddell Sea, J. Geophys. Res. 95(C6), 9513-9525.

Madec, G., P. Delecluse, M. Imbard, and C. Lévy (1999), OPA 8.1 Ocean General Circulation Model Reference Manual, Notes du Pôle de Modélisation, 91 pp., Inst. Pierre-Simon Laplace, Paris.

Multala, J., H. Hautaniemi, M. Oksama, M. Leppäranta, J. Haapala, A. Herlevi, K. Riska, and M. Lensu (1996), An airborne electromagnetic system on a fixed wing aircraft for sea ice thickness mapping, Cold Reg. Sci. Technol., 24, 355-373.

Rothrock, D. A., J. Zhang, and Y. Yu (2003), The Arctic ice thickness anomaly of the 1990s: A consistent view from observations and models, J. Geophys. Res., 108(C3), 3083, doi:10.1029/2001JC001208.

Semtner, A. J., Jr. (1976), A model for the thermodynamic growth of sea ice in numerical investigations of climate, J. Phys. Oceanogr., 6(3), 379389

Strass, V. H., and E. Fahrbach (1998), Temporal and regional variation of sea ice draft and coverage in the Weddell Sea obtained from upward looking sonars, in Antarctic Sea Ice: Physical Processes, Interactions and Variability, Antarct. Res. Ser., vol. 74, edited by M. O. Jeffries, pp. 123-139, AGU, Washington, D. C.

Timmermann, R., A. Beckmann, and H. H. Hellmer (2002), Simulation of ice-ocean dynamics in the Weddell Sea: 1 . Model configuration and validation, J. Geophys. Res., 107(C3), 3024, doi:10.1029/2000JC000741. Timmermann, R., H. Goosse, G. Madec, T. Fichefet, C. Ethe, and V. Dulière (2004), On the representation of high latitude processes in the ORCALIM global coupled sea ice-ocean model, Ocean Modell., Hooke Inst., Oxford Univ., Oxford, UK, in press. 
Tin, T., R. Timmermann, and M. O. Jeffries (2004), On the evolution of sea ice thickness in the Ross Sea 1998/1999, J. Glaciol., in press.

Trenberth, K. E., J. G. Olson, and W. G. Large (1989), A global ocean wind stress climatology based on the ECMWF analyses, Rep. NCAR/TN$338+S T R, 93$ pp., Natl. Cent. Atmos. Res., Boulder, Colo.

Windmüller, M. (1997), Untersuchung von atmosphärischen Reanalysedaten im Weddellmeer und Anwendung auf ein dynamisch thermodynamisches Meereismodell, M.S. thesis, 65 pp., Inst. für Meereskunde an der Christian-Albrechts-Univ., Kiel, Germany.

Worby, A. P. (1999), Observing Antarctic Sea Ice: A Practical Guide for Conducting Sea Ice Observations From Vessels Operating in the Antarctic Pack Ice [CD-ROM], Sci. Comm. for Antarct. Res., Hobart, Tasmania, Australia.

Worby, A. P., and I. Allison (1999), A technique for making ship-based observations of Antarctic sea ice thickness and characteristics, part I: Observational technique and results, in Observing Antarctic Sea Ice: A Practical Guide for Conducting Sea Ice Observations From Vessels Operating in the Antarctic Pack Ice [CD-ROM], edited by A. P. Worby, pp. 1-23, Sci. Comm. for Antarct. Res., Hobart, Tasmania, Australia.

Worby, A. P., R. A. Massom, I. Allison, V. I. Lytle, and P. Heil (1998), East Antarctic sea ice: A review of its structure, properties and drift, in Ant- arctic Sea Ice: Physical Processes, Interactions and Variability, Antarct. Res. Ser., vol. 74, edited by M. O. Jeffries, pp. 41-67, AGU, Washington, D. C.

Xie, P., and P. A. Arkin (1996), Analyses of global monthly precipitation using gauge observations, satellite estimates and numerical model predictions, J. Clim., 9, 840-858.

T. Fichefet and H. Goosse, Institut d'Astronomie et de Géophysique Georges Lemaître, Université Catholique de Louvain, Chemin du Cyclotron 2, B-1348 Louvain-la-Neuve, Belgium. (fichefet@astr.ucl.ac.be; hgs@astr. ucl.ac.be)

R. Timmermann, Alfred Wegener Institute for Polar and Marine Research, Postfach 120161, D-27515 Bremerhaven, Germany. (rtimmermann@ awi-bremerhaven.de)

A. Worby, Department of the Environment and Heritage, Australian Antarctic Division and the Antarctic Climate and Ecosystems CRC, Channel Highway, Kingston, Tasmania 7050, Australia. (a.worby@utas. edu.au) 